\title{
From relational equality to personal responsibility
}

\author{
Andreas T. Schmidt ${ }^{1}$ (D)
}

Accepted: 28 July 2021/Published online: 1 September 2021

(C) The Author(s) 2021

\begin{abstract}
According to relational egalitarians, equality is not primarily about the distribution of some good but about people relating to one another as equals. However, compared with other theorists in political philosophy - including other egalitarians - relational egalitarians have said relatively little on what role personal responsibility should play in their theories. For example, is equality compatible with responsibility? Should economic distributions be responsibility-sensitive? This article fills this gap. I develop a relational egalitarian framework for personal responsibility and show that relational equality commits us to responsibility. I develop two sets of arguments. First, I draw on relational theories of moral responsibility - particularly Strawsonian views - to show that valuable egalitarian relationships require responsibility. Second, I show why relational equality sometimes requires that economic distributions be sensitive to responsibility and choice. I also defend a seemingly paradoxical result: being committed to responsibility, relational egalitarianism not only justifies some distributive inequalities but some relational inequalities too. Overall, relational egalitarianism gives a nuanced and coherent answer as to why and how responsibility matters from within egalitarianism. That it does should be an important argument in its favour.
\end{abstract}

Keywords Equality $\cdot$ Inequality $\cdot$ Relational egalitarianism $\cdot$ Personal responsibility $\cdot$ Choice $\cdot$ Luck egalitarianism - Distributive justice

Andreas T. Schmidt

a.t.schmidt@rug.nl

1 Faculty of Philosophy, University of Groningen, Oude Boteringestraat 52, 9712 GL Groningen, The Netherlands 


\section{Introduction}

According to relational egalitarianism, equality is not primarily about the distribution of some good. Instead, at its core stands the vision of a society wherein individuals relate to one another as equals. Accordingly, relational egalitarians identify oppression, domination, discrimination and so on as the central enemies of egalitarianism. ${ }^{1}$

However, compared with other theorists - including other egalitarians relational egalitarians have said relatively little on what role they accord to personal responsibility. For example, is equality compatible with responsibility? Should economic distributions be responsibility-sensitive? Of course, relational egalitarians have written much on where they think luck egalitarians go wrong in their invocation of responsibility. But relational egalitarians have so far done little to offer an alternative view of responsibility. This is a striking lacuna. For one, without an account of responsibility, relational egalitarians might struggle to win over 'nonegalitarians' who place great value on individual choice and responsibility. Moreover, it is not just academic philosophers who think distributions should be sensitive to responsibility. Survey research suggests most people believe that, while outcome equality is important, economic distributions should also be about responsibility and desert (Miller, 1999, chap. 4).

This article fills this lacuna. Through a series of arguments, I construct a relational egalitarian framework for responsibility. I argue that relational equality itself commits us to personal responsibility. Relational egalitarianism itself grounds a commitment to personal responsibility and shows why some distributions should be sensitive to personal responsibility and choice. This result makes for a new positive argument for relational egalitarianism.

I present two sets of arguments.

First, drawing on relational theories of moral responsibility - particularly Strawsonian views - I argue that a commitment to relational equality implies a commitment to holding one other responsible.

Second, I argue that relational equality sometimes requires that economic distributions be sensitive to responsibility. Relational egalitarianism thus accounts for central intuitions around responsibility in economic distributions. Moreover, instead of marrying two alien ideas - equality and responsibility - relational egalitarianism shows how responsibility-sensitivity grows out of relational equality itself. In distinguishing synchronic from diachronic relational equality, I also defend a seemingly paradoxical claim: relational egalitarianism sometimes not only justifies distributive inequalities but some relational inequalities too.

\footnotetext{
${ }^{1}$ For contemporary relational egalitarianism, see (Anderson, 1999, 2008, 2010; Fourie et al., 2015; Kolodny, 2014, 2019; Lippert-Rasmussen, 2018; Miller, 1997; O’Neill, 2008; Scanlon, 2018; Scheffler, 2003, 2015; Schemmel, 2011; 2012; Wolff, 1998; Young, 1990, chaps 1; 2). Similar issues are found in Critical Theory writings (Fraser \& Honneth, 2003; Honneth, 1992) and, according to (Wolff, 2015), already in Marx's Critique of the Gotha Programme and in (Tawney, 1931). Finally, relational egalitarianism has overlap with neo-republicanism (Pettit 2014; Skinner, 2012; Laborde \& Maynor, 2009; Lovett, 2010; Schmidt, 2018) but also differs from it (Garrau \& Laborde, 2015; Kolodny, 2019; Krause, 2013).
} 
I proceed as follows. In Sect. 2, I explain how personal responsibility creates a challenge for egalitarian theories. In Sect. 3, I lay out relational egalitarianism. In Sect. 4, I present a theoretical argument connecting relational equality and responsibility. In Sect. 5, I argue that relational egalitarianism implies that economic distributions should sometimes be sensitive to responsibility. In Sect. 6, I address two worries about responsibility-sensitive relational egalitarianism and conclude in Sect. 7.

\section{The responsibility challenge}

I now introduce what I call the Responsibility Challenge to egalitarianism. To understand this challenge, first consider different ways to be an egalitarian.

Distributive egalitarianism holds that egalitarian distributive justice is about an equal distribution of some good. However, not all outcome inequalities are equally unjust. As a species of distributive egalitarianism, luck egalitarianism holds that inequalities are unjust only when they are due to (brute) luck but not unjust when they are due to people's choices (provided individuals had sufficiently equal starting positions) ${ }^{2}$ Cohen's popular proposal, for example, is that inequalities are unjust, if they result from factors for which individuals are not responsible (Cohen, 1989). To connect distributive egalitarianism with choice and responsibility, luck egalitarians look for a 'distribuendum' - such as opportunities - with choice-sensitivity already built into it (Arneson, 1991; Cohen, 1989; Roemer, 2000).

In recent decades, relational egalitarianism has emerged as luck egalitarianism's main competitor. Pace distributive egalitarianism, relational egalitarians argue we should focus on how people relate to one another, which cannot be captured by the distribution of some good. ${ }^{3}$ Pace luck egalitarianism, relational egalitarians hold that equality is not about compensating or offsetting good and bad (brute) luck.

In this article, I assume any plausible egalitarian theory should have a good answer to the Responsibility Challenge: such theories should (i) provide a general account of how equality and responsibility relate and (ii) return intuitive judgements, along with a theoretical rationale, in cases where responsibility seems to justify distributive inequality. Regarding (ii), consider:

\footnotetext{
2 See (Arneson, 1989, 1991; Cohen, 1989, 2009a, 2009b; Eyal, 2006; Knight, 2006, 2009; Kymlicka, 2002, 71 - 85; Lippert-Rasmussen, 2015; Rakowski, 1991; Roemer, 2000; Segall, 2010, 2013; Stemplowska, 2008, 2009, 2011, 2013). Dworkin is often classified as a luck egalitarian, although he rejects the label (Dworkin, 1981). (Tan, 2008; 2012) is an institutional, 'in-between' version of luck egalitarianism. An overlooked 'proto-luck-egalitarian' view is (Spiegelberg, 1944).

3 Some think relational egalitarianism is a form of distributive egalitarianism, just with a distribuendum that includes things like 'social status'; others disagree (Cordelli, 2015; Elford, 2017; Gheaus, 2016; Moles and Parr, 2019). My focus is on the contrast between relational and luck egalitarianism (rather than distributive egalitarianism), so the dispute is largely irrelevant here.
} 
Money Burner: Petra receives her salary twice a year. Yet upon receiving her salary, Petra burns $90 \%$ of it, which leaves her destitute.

Lecturer: Tim works as a university lecturer. Yet he only rarely shows up for class, does no research, and is nearly always unavailable. His colleague Jane, in contrast, performs all her professional obligations dutifully.

Helicopter: a remote, poor, and mountainous society must decide how to spend scarce resources. It can either buy a rescue helicopter with which it would save ten reckless hikers per year. Or it can buy a critical care device that would cure ten persons per year from an unpreventable infection (see Eyal, 2016, 168-69).

\section{How should relational egalitarians respond to the Responsibility Challenge?}

At first blush, they seem to struggle. Consider first a caricature of relational egalitarianism. Imagine Equalia, a society bent on minimising relational inequalities. Equalia's institutions are set up such that Petra's lack of resources will be compensated to the point where she again stands in perfect relational equality with all other citizens. In Lecturer, Equalia would make it next to impossible to make Tim redundant. Or, if Equalia allowed for Tim to be sacked, he would receive all the resources necessary to keep him at an equal standing with everyone else, including Jane. In Helicopter, Equalia's commitment to relational equality provides no reason to spend the money either way. ${ }^{4}$ But, of course, Equalia is a caricature of relational egalitarianism. At least the relational egalitarians I have met agree that personal responsibility matters in cases like those above. So, what theoretical options do they have?

First, some egalitarians adopt a hybrid of relational and luck egalitarianism. ${ }^{5}$ Some versions of luck egalitarianism could provide an intuitive account of the above cases. They might conclude that it is justifiable for Petra to be worse off in Money Burner, for Tim to be worse off than Jane, and for the mountainous society

\footnotetext{
4 Some relational egalitarians might retort that they already make institutional proposals that would handle cases like Lecturer and Money Burner [such as Anderson's capability minimum (Anderson 1999)]. However, pointing to individual institutional proposals does not yet meet the Responsibility Challenge. Before engaging with specific institutional proposals, I here take a step back and first unearth a deeper theoretical connection between relational equality and responsibility.

5 Some egalitarians find such a combination attractive (Lippert-Rasmussen 2015; 2018; Moles and Parr 2019; Wellman 2008, 121-23), whereas most relational egalitarians would probably hesitate, considering the many objections they have raised to luck egalitarianism, including: the choice-circumstance distinction disregards that inequalities resulting from social structures are more troubling than inequalities resulting from 'non-social' factors (Young 1990, chap. 1); luck egalitarianism (and distributive egalitarianism more generally) fails to consider that inequalities are not only about what we get but also about how we are treated (Anderson, 1999; Pogge, 1995; Schemmel, 2012); luck egalitarianism would require government intrusion (Anderson, 1999; Scheffler, 2003; Wolff, 1998); luck egalitarianism has an implausibly wide scope; is sometimes too harsh (Anderson, 1999; Fleurbaey, 1995; Scheffler, 2003); builds on a simplistic yet unrealistic distinction between choice and circumstance (Scheffler, 2003); and lands us problematically deep in the free will problem (Fleurbaey, 2008, chap. 10). In Sect. 6.2, I discuss two more. Of course, luck egalitarians respond to those objections (and sometimes adjust their views), for example (Eyal, 2006, 2016; Lippert-Rasmussen, 2015, Segall, 2013; Stemplowska, 2008, 2009, 2013, 2011; Tan, 2008; 2012).
} 
to buy the critical care device. If so, luck egalitarianism could be added to meet the Responsibility Challenge.

The second option is to reject luck egalitarianism but supplement relational equality with other, non-egalitarian reasons to value responsibility. For example, respecting personal responsibility might be necessary to deliver more efficient economic outcomes but also to respect choice and autonomy (McTernan, 2016). Emily McTernan, for example, argues that such plausible practice-based reasons for responsibility chime well with relational egalitarianism.

In this article, I defend a third option. I argue that responsibility is part of relational equality. A commitment to responsibility practices already inheres in our commitment to relational equality itself. My arguments will meet the Responsibility Challenge by not only producing intuitive judgments but also providing a deeper justification for why, as egalitarians, we should care about responsibility. My position differs from the first two options. First, unlike a hybrid view, my view is relational all the way down. My arguments show egalitarians can include responsibility without luck egalitarianism. Second, I argue that responsibility practices are not only compatible with relational egalitarianism but defend a stronger connection, namely that some are implied by relational equality itself. ${ }^{6}$

Let me first say a bit more about relational egalitarianism.

\section{Relational egalitarianism}

In relational egalitarian societies, institutions should be such that individuals relate to one another as equals. Here are four points to spell this out.

First, relating as equals typically involves an attitudinal and a behavioural part. Relational equality implies regarding the other person as an equal and treating them as such (Cohen, 2013, 197; Lippert-Rasmussen, 2018, chap. 3).

Second, we can relate to one another as equals in different social relationships, such as co-citizens, neighbours, friends, strangers in a café, family members, or coworkers. Equal and unequal relations can also obtain 'vertically' between individuals and non-individual agents or entities. For example, state authorities might treat individual citizens in ways that undermine their equal standing.

Within relations, inferior standing can be assigned along different dimensions (Lippert-Rasmussen, 2018, chap. 3.2). I might regard someone as a moral inferior such that I regard or treat their interests as mattering less than mine (LippertRasmussen, 2018, chap. 3.2; Scheffler, 2015), regard someone as epistemically inferior (Fricker, 2007), or regard someone as inferior simply in terms of social standing. In practice, of course, these dimensions often overlap greatly (LippertRasmussen, 2018, chap. 3.2).

\footnotetext{
${ }^{6}$ My arguments are not a critique of McTernan, whose arguments, while different, are congenial to mine.
} 
Third, relating as equals, or as unequal, is sometimes not reducible to how two individuals view or treat each other - often the social context matters:

Carlton: Bella works as a bouncer at a night club. She is instructed to admit at most a few Black persons per night. Bella herself is Black and working class. One night a group of wealthy private school boys arrive. Among them is Carlton, a Black student with a rich Belair background. Bella lets in all the rich white boys but sends Carlton away.

Carlton does not relate to his white friends (and other white customers) as an equal. Yet the problem is not that Carlton's white friends treat him as an inferior (assume they treat him as an equal). Nor does Bella treat Carlton as an inferior to herself. Rather, facing discrimination, Carlton is not treated as an equal relative to white customers. ${ }^{7}$ Carlton shows that relational inequality can often depend on social context. It is often mediated by the social meaning of relationships and people's comparative status in the eyes of others.

Fourth, relational egalitarianism contains both a 'negative' and a 'positive' message. The 'negative' message is that we ought to eradicate strong relational inequalities (Wolff, 2015). Following Iris Marion Young, for example, relational egalitarians should want to eradicate domination and the 'five faces of oppression': exploitation, marginalisation, powerlessness, cultural imperialism, and violence (Young, 1990, chap. 2). But relational egalitarianism also carries a positive message. An egalitarian society is not only free of the gravest injustices but also positively attractive to live in. ${ }^{8}$ Such a society would likely come with important personal benefits. Much empirical literature discusses how equality can be good for health and wellbeing. ${ }^{9}$ But relational egalitarians further stress that such societies would also facilitate inherently egalitarian and relational goods, such as the absence of oppression, domination and, more positively, good conditions for entering and cultivating relationships between equals. ${ }^{10}$

Before moving on, note two clarifications about the version of relational egalitarianism I work with here.

First, egalitarianism is typically understood as a theory of justice. But as David Miller argues, not all claims of justice are about equality (Miller, 1997). At the same time, I take relational egalitarianism to be wider in that some claims are not primarily about justice. Some reasons have an 'axiological flavour', as equality

\footnotetext{
7 The nightclub's power to send customers away might also be a source of relational inequality. However, what arguably matters more is that the nightclub sends Carlton away for discriminatory reasons. We would have a different intuition if the nightclub randomly selected people by flipping a coin.

${ }^{8}$ See, for example, (O’Neill 2008; Wolff and de-Shalit 2013, 122; Young 1990, 37).

${ }^{9}$ See (International Panel on Social Progress 2018, chap. 3) for an overview of empirical effects of inequality. Also see (Gruen and Klasen 2013; Morgan et al., 2007; Oishi et al., 2011; O'Neill 2010; Pickett and Wilkinson 2015; Schuppert 2012).

${ }^{10}$ I leave open whether such egalitarian goods are intrinsically or only instrumentally valuable. Even if only instrumentally valuable, their benefits are, first, very important and, second, non-specific such that they are robustly valuable across most conceptions of the good. Also see (O'Neill 2008).
} 
helps us facilitate valuable relationships and relational goods (O'Neill, 2008; Wolff and de-Shalit 2013, 122).

Second, most relational egalitarians build their social ideal on a deeper philosophical basis. For example, Scheffler's theory is based on equal respect and the 'egalitarian deliberative constraint', Anderson's theory contractualist, Fraser and Honneth's quasi-Hegelian, and others invoke dignity, freedom as non-domination, or something else. ${ }^{11}$ I here broadly follow Miller and discuss relational equality as a social ideal without deriving it from a deeper philosophical theory (Miller, 1997, 234). I here present relational egalitarianism as a view that is distinctive primarily in virtue of its normative claims about how we should structure social practices, relations, and institutions. Moreover, this social ideal is meant to be available across different relational egalitarian views despite their underlying normative differences. So, my version of relational egalitarianism aims to be sufficiently distinctive in its normative claims about social life whilst also keeping sufficient 'metanormative neutrality'.

\section{The connection argument}

I now argue that relational equality implies responsibility. ${ }^{12}$

A. Relational egalitarians prescribe social conditions under which valuable egalitarian relationships can flourish.

B. Most, or at least many, of those egalitarian relationships can only flourish, if participants are disposed to hold one another responsible.

C. Therefore, relational egalitarians prescribe social conditions under which participants are disposed to hold one another responsible.

I call this the Connection Argument, because it outlines the fundamental connection between relational equality and personal responsibility. Premise A is an implication of relational egalitarianism as outlined in 3. I now draw on pragmatic, relational theories of responsibility - particularly Strawsonian views - to defend premise B. I argue (i) that most valuable relations require responsibility dispositions and that the general case simply extends to (most) egalitarian relations. I also argue that (ii) those relations being egalitarian calls for responsibility. While I here invoke Strawsonian theories, my argument would also work, mutatis mutandis, with other relational theories, such as Tim Scanlon's (Scanlon, 2008). Let us start with (i).

P.F. Strawson's theory of responsibility is relational (or 'pragmatic'). His analysis starts with our practices of holding one another responsible and their role in social life. Strawson holds that such practices involve reactive attitudes. Reactive

\footnotetext{
11 See footnote 1 above for references.

12 Obviously, relational equality is one but not the only reason why responsibility practices are valuable. Also see footnote 6 above.
} 
attitudes are central aspects of interpersonal relationships and include blame, gratitude, resentment, and forgiveness. Reactive attitudes express.

... how much we actually mind, how much it matters to us, whether the actions of other people — and particularly some other people-reflect attitudes towards us of good will, affection, or esteem on the one hand or contempt, indifference, or malevolence on the other. (Strawson, 1962, 5)

For participants in social relations, reactive attitudes are typically inevitable. Strawson calls this the 'participant attitude'. Typically, such reactive attitudes also connect with the normative expectations underlying our relationships (Wallace, 1994, chap. 2.2.). For example, if you are my friend, I expect you to respond to the right normative considerations in your attitudes and behaviour towards me. With such expectations typically comes a disposition to respond with negative reactive attitudes should your actions grossly violate such expectations. For example, if I discover that you have been badmouthing me, I will typically have some negative reactive attitude, such as disappointment or blame. More generally, norms and normative expectations typically come with dispositions to have reactive attitudes.

Dispositions to hold someone responsible - henceforth responsibility dispositions - play different functions within interpersonal relationships. Let me highlight two.

First, responsibility dispositions partly constitute some interpersonal relationships. Among many other things, a friendship, for example, is constituted by the normative expectations friends have towards one another. And such expectations typically require responsibility dispositions.

Second, reactive attitudes have communicative functions. Expressing such attitudes can help express the normative expectations that underlie a relationship or help us enter a discussion or negotiation about what such expectations should be (Fricker, 2016; Holroyd, 2007; McKenna, 2012). ${ }^{13}$ Relatedly, expressing reactive attitudes also conveys a message about the recipient and one's relationship with them, it is a form of moral address. Building on Strawson, Tori McGeer holds that expressing reactive attitudes.

... says to their recipients that we don't despair of them as moral agents; that we don't view them "objectively" - as individuals to be manipulated or managed or somehow worked around... So reactive attitudes communicate a positive message even in their most negative guise... The fact that we express them says to their recipients that we see them as individuals who, going forward, can certainly do better in understanding and living up to the norms that make for moral community. (McGeer, 2014, 77)

If these relational theories hold up, they provide the first argument for premise B. First, many valuable relations can only exist and flourish if participants hold one another responsible. Second, most (or at least many) egalitarian relationships are of that nature too. Therefore, most - or at least many - of those egalitarian

\footnotetext{
13 Political philosophers will recognise similar ideas from communicative theories of punishment (Duff 2003; Hirsch 1996, chap. 2; Wood 2010, 475-80).
} 
relationships can only flourish, if participants are disposed to hold one another responsible. For example, marriages require responsibility dispositions. But by extension, egalitarian marriages should too. Relational egalitarianism covers many different relations, such as workplace relations, romantic relationships, relations between neighbours, relating as political equals and so on. Those are egalitarian relations to which the pragmatic view on responsibility applies. Even in abstract egalitarian relationships does responsibility typically matter. Take political relations for example. Norms matter for functioning democracies (Pettit 2014, 134; Sunstein, 1988, 1548-51). Some such norms are legally enforceable, others informal, and others a mix of the two. Relating as co-citizens, for example, implies informal norms and normative expectations and, with those, responsibility dispositions. By extension, relating as political equals will also feature normative expectations and responsibility dispositions. ${ }^{14}$

I now also advance (ii), a finer, egalitarian argument for premise B: the specifically egalitarian character of some relations often commits us to responsibility too. Consider how Strawson imagines what social relationships would be like, if we left the participant attitude and adopted the objective attitude.

To adopt the objective attitude to another human being is to see him, perhaps, as an object of social policy; as a subject for what... might be called treatment; as something certainly to be taken account of...; to be managed or handled or cured or trained; perhaps simply to be avoided... it cannot include the range of reactive feelings and attitudes which belong to involvement or participation with others in interpersonal human relationships; it cannot include resentment, gratitude, forgiveness, anger, or the sort of love which two adults can sometimes be said to feel reciprocally, for each other. (Strawson, 1962, 126-27)

Egalitarian relationships and the objective attitude typically do not go together. Viewing you through the objective attitude, I might fail to regard you as my equal. To regard others as objects whom one either views as incapable of responding to normative considerations or alternatively as unworthy of reactive attitudes implies an inegalitarian attitude towards them.

Again, while the argument is most salient in involved interpersonal relationships, it applies more broadly. For example, I might view other citizens as pawns that I can manipulate into having what I think are the right beliefs or party preferences. But a more respectful egalitarian way to relate to other citizens likely involves viewing them as moral agents in a political community. As such - and when background conditions are favourable - I view them as co-participants I can reason with and as agents who can be held responsible for their actions and views.

To further unpack this argument, consider a potential worry a reader might have. Can we not combine egalitarianism and the objective attitude? Could we not just all

\footnotetext{
14 Viehoff, for example, argues that political relational equality is closely linked to what relational equality requires in personal relationships (Viehoff, 2014, 361-64).
} 
'level down' and treat each other equally through the objective attitude? ${ }^{15}$ Imagine a society, call it Objectivia, where people do not have any relationships involving reactive attitudes and in which they view each other through the objective attitude. One might now object that while Objectivia would seem less valuable, it would be no less egalitarian than a society where people have involved relationships and hold one another responsible.

However, this objection fails.

The first problem is that such a consistent and equal adoption of the objective attitude might simply be unfeasible. Strawson - and Hume before him - argues that humans can hardly escape responsibility dispositions, which makes it unlikely we can treat everyone through the objective attitude (Hume, 1739, sec. II.ii.1-2; Russell, 2002; Strawson, 1962). Similarly, many of the norm-governed practices and institutions that help make our societies work would be hard to sustain if we all adopted the objective attitude. Moreover, we might also wonder whether levelling down is possible given that we should find it hard to treat ourselves through the objective attitude. We typically think of ourselves as capable of responding to reasons and can be angry at our failings and proud of our achievements. Keeping this attitude towards ourselves yet treating others through the objective attitude, we would then still fail to regard others as equals.

Such infeasibility worries matter methodologically. I here understand relational egalitarianism as a social ideal of how to structure relations, practices, and institutions in real-life contexts. Importantly, such an ideal takes certain psychological and social facts as given. For example, relational egalitarianism assumes that (most) people have an interest in having social relationships or that successful societies require (some) norm-governed practices and institutions. Because of such assumptions, unrealistic thought experiments, like Objectivia, are not powerful counterexamples.

Beyond infeasibility, two further responses ward off the objection.

First, relational egalitarianism is not a merely negative view. Relational egalitarianism's positive message is that favourable conditions for egalitarian relations make societies better. And because such relations typically imply normative expectations, relational egalitarians should be against levelling down to the objective attitude. Even if feasible, disvaluable 'egalitarian' relationships - like in Objectivia - are simply not as good as valuable egalitarian relationships nor are they the next best thing.

Finally, relational egalitarianism shows that, under normal conditions, Objectivia is in one respect less egalitarian than a society where we have egalitarian relationships involving responsibility dispositions. If I manipulate you and do not take you seriously as a moral agent, I do not regard or treat you as an equal. However, your manipulating me back and treating me the same way does not annul my inegalitarian regard and treatment. I treat you as an unequal and you treat me as an unequal. The result is not equality but 'mutual inequality'.

$\overline{15}$ Thanks to Nir Eyal for this point and to a reviewer for pressing me on this. 
Consider now a second, more theoretical worry. To defend premise B, I have drawn on relational theories of responsibility. However, a common worry about such theories is that they fail to tell us whether, or when, responsibility attributions are independently justifiable. To appreciate this criticism, distinguish two usages of 'responsibility'.

First, 'being responsible for an action $x$ ' and 'holding you responsible for $x$ ' can mean that $x$ can be attributed to you in a way that makes it appropriate to take $x$ as a basis of a moral appraisal of you (Scanlon, 1998, chap. 6). Scanlon calls this responsibility as attributability. Attributability does not imply that $x$ has a particular moral quality: $x$ could be right, wrong, or neutral. Alternatively, 'holding you responsible for $x$ ' can mean that you are made to bear some consequence for $x$. Call this consequential responsibility (Stemplowska, 2008, 355-56). Such consequences include informal consequences like being praised or blamed and substantial consequences like punishment and being made better or worse off economically.

We typically assume the appropriate application of consequential responsibility implies attributability. So, to assess responsibility dispositions and practices, it seems we ought to first develop objective conditions of appropriateness. With objective conditions in place, we can then justify or criticise practices of consequential responsibility. However, a view such as Strawson's rejects this order. Strawson contends that the standards of appropriateness people use lie inside the practice rather than being shaped by external, objective standards. Yet Strawson's view invites an unsurprising objection: we want to know not only how people hold each other responsible but also whether they are justified in doing so. And Strawson's view seems to lack such an external justification.

As I see it, relational egalitarians have two different responses.

First, my argument does not assume that pragmatic views give us the correct overall view of responsibility. Instead, according to the ameliorative response, my argument only relies on the plausible descriptive component of pragmatic theories. It is largely non-committal on whether independent, objective criteria for appropriateness exist and, if so, what those might be. My argument allows that such external criteria ought to influence what responsibility dispositions people should have and, with it, what forms egalitarian relations should take. If some such relations required inappropriate blaming, for example, then a relational egalitarian would have reason not to recommend them. But such external criteria - whatever they are - are unlikely to imperil the relational egalitarian project. $^{16}$

The second, more radical answer would follow relational theories not only in their descriptive but also their justificatory project. Several relational theorists hold that appropriateness criteria are internal to the practice (Barrett, 2020; McGeer, 2012, 2014; Pettit, 2001; Vargas, 2013). But not all criteria are equally good, because not all practices and interpersonal relationships are equally good. Different responsibility practices enable different kinds of social relations through the constitutive and communicative functions explored above (alongside other functions). Accordingly, we can glean the appropriate norms of attributing

\footnotetext{
${ }^{16}$ If those external criteria are a threat to responsibility dispositions in our practices and relations, they would just as likely threaten the luck egalitarian and the 'conservative' responsibility project.
} 
responsibility from how they would enable valuable social relations. I am sympathetic to this approach to moral responsibility. However, given limited space, I merely point to it as a possibility. Instead, I carry on assuming my argument works with both the ameliorative and the radical response.

I earlier stipulated that, to meet the Responsibility Challenge, relational egalitarianism should (i) provide a general account of how equality and responsibility relate and (ii) return intuitive judgements, along with a theoretical rationale, in cases where responsibility seems to justify distributive inequality. In this section, I have defended the Connection Argument. This argument goes some way towards meeting (i): it shows why relational egalitarianism commits us to responsibility practices. However, it alone does not tell us what consequential responsibility practices egalitarian societies should endorse. Accordingly, it does not yet tell us whether - and if so how - economic distributions should track responsibility in Money Burner, Lecturer, and Helicopter. ${ }^{17}$ This is the task I take up now.

\section{Responsibility and economic distributions}

I now show why and how relational equality implies that economic distributions should sometimes be sensitive to responsibility.

\subsection{Diachronic relational equality and equal participation}

First, we need to think about time. I earlier introduced 'Equalia' as a caricature of relational egalitarian institutions. In Equalia, society tries to secure relational equality. But it fails to do so, because Equalia takes a mere snapshot view of relational equality and neglects how relations extend across time. For example, in Money Burner, it matters not only in what relationships Petra stands now - call this synchronic relational equality - but also how she relates to others before and after - call this diachronic relational equality. As Lippert-Rasmussen argues, relational egalitarianism should be about both synchronic and diachronic equality (Lippert-Rasmussen, 2018, chap. 5). ${ }^{18}$ Concerns around responsibility - I shall argue - provide another case in point.

I take synchronic equality to cover relatively short time frames (rather than literally just points in time). Economic distributions clearly affect synchronic equality. Relational egalitarianism thus favours distributions with an egalitarian

\footnotetext{
17 Other forms of consequential responsibility matter too, of course, including punishment, blaming and praising. I exclude these issues here given limited space - except for the following caveat. Relational egalitarians should of course neither welcome all forms of consequential responsibility nor 'maximise responsibility'. First, some responsibility practices actively undermine relational equality. For example, punitivism can threaten relational equality (Koch 2019). Second, egalitarian relations potentially require, or work with, only some of the reactive attitudes Strawson talks about. For example, shame and embarrassment might be deleterious. (See, for example, (Wallace 1994, chap. 2.2).) Finally, rather than 'being judgemental', relational equality can sometimes also prescribe norms to the effect that individuals and the state are expected to suspend judgement of others.

18 See (McKerlie 1989; 2001) and particularly (Lippert-Rasmussen 2018, chap. 5) on related questions around time.
} 
slant (Scanlon, 2018, chap. 3; Schemmel, 2011). For example, economic disadvantage often comes with lower social status and, along with it, often shame, deference, and lowered self-respect. Economic inequality can also creep into our private lives. Women earning much less than men can stand in the way of egalitarian romantic relations. Of course, our relations to one another in the economic sphere are not just about income and wealth. For example, synchronic equality also militates against strongly hierarchical workplace relations.

Consider diachronic equality next. To answer the Responsibility Challenge, we require a picture of how we can relate as equals in productive activity and economic distributions across time. But diachronic equality is more than just the aggregate of synchronic equalities. ${ }^{19}$ A broader diachronic picture should attend to the procedures and institutions that form the background to our interactions and relations across time. In this article, I talk about relational egalitarianism as a family of views. Now, each specific conception of relational egalitarianism will come with its own view of economic relations to fill in diachronic equality. Given limited space, I can here neither go through them all. So, instead, I present two broad requirements that should resonate across conceptions. To relate to one other as equals diachronically in economic matters, I will say that people should relate as equal participants in a cooperative undertaking for overall advantage (which I mostly abbreviate to 'equal participants' and 'equal participation'). Such an ideal will give us a sense of the necessary institutional background for diachronic equality. Against this background, I then argue that not only are synchronic inequalities - both economic and relational - sometimes compatible with relational egalitarianism, diachronic equality sometimes necessitates such inequalities.

The two requirements of equal participation are, first, that institutions sufficiently fulfil (i) the Institutional Justification Requirement and (ii) the Equal Footing Requirement. Start with (i).

(i) The institutional justification requirement

In economic interactions, we cooperate to produce benefits, such as build houses, run universities, and trade. Cooperation for overall advantage can happen in very different institutional set-ups, including laisser-faire capitalism, social democracy, and socialism. Different institutions produce different kinds and levels of benefits, such as public goods, health, wealth, stable right protections, and fun consumer goods. The first trivial point is that for some institutions to be preferable over others, such institutions require a justification invoking the benefits they generate (Scanlon, 2018, chaps 4; 9). The next point is that for relational egalitarians, such a justification should meet certain egalitarian conditions, at least the following three. ${ }^{20}$

\footnotetext{
${ }^{19}$ See (Lippert-Rasmussen 2018, chap. 5) for another argument as to why diachronic relational equality is more than the aggregate of synchronic equality.

${ }^{20}$ Some relational egalitarians discuss what the 'site' of equality is: is relational equality primarily or even exclusively about the basic structure or does it apply more broadly (see (Lippert-Rasmussen 2018, 136-46) for example)? On the former view, the Institutional Justification Requirement would apply only to the basic structure but would be wider on the latter. I lean towards the latter but remain (mostly) neutral on this question here.
} 
First, in considering the benefits (wealth, health, consumer goods etc.) and burdens (pollution, need for coordination, taxes etc.) that institutions produce, an egalitarian justification must consider everyone's interests (Anderson, 2010; Scanlon, 2018; Scheffler, 2015). This constraint leaves room for many types of justification but rules out those that focus narrowly on few people. For example, egalitarians are not impressed with institutional justifications that focus only on the interests of the superrich, a privileged race, or aristocrats. ${ }^{21}$

Second, a relational egalitarian justification concerns itself not only with 'extrinsic' benefits, such as roads, GDP and so on, but also with the kinds of relations different institutions would constitute and produce. A relational egalitarian should care about whether, or how far, institutions would generate synchronic relational inequalities or equalities. ${ }^{22}$

Finally, an egalitarian justification would typically curb how much economic inequality would be acceptable. Economic inequalities can engender synchronic relational inequalities. Moreover, economic inequality can be highly suboptimal, because economic resources tend to make decreasing marginal contributions to people's wellbeing and other personal goods. Of course, I remain somewhat neutral between different conceptions of relational egalitarianism. And those conceptions might differ in how much economic inequality they might allow. But we can reasonably assume that relational egalitarianism would want to curb excessive inequality and, when such inequality is strong, require a justification. ${ }^{23}$

When Institutional Justification is fulfilled, we already have an easier time justifying synchronic economic inequalities: an inequality in holdings between two persons might not threaten diachronic equality, provided the inequality has come about through justified institutions. But Institutional Justification can be insufficient to secure diachronic equality. Sometimes it matters how particular synchronic inequalities come about. So, we require a second requirement.

(ii) The equal footing requirement

People should be able to participate on an equal footing. This requirement has two components.

First, the ways specific benefits and burdens are distributed - and inequalities can result - must fulfil procedural conditions (Rawls, 1971, sec. 14; Scanlon, 2018, 41). For example, procedural fairness might require that standards be applied consistently and fairly and that distributive decisions be free of discrimination. Individuals

\footnotetext{
${ }^{21}$ Contractualist versions of relational egalitarianism theorise this requirement by requiring that institutions be justifiable to everyone (Anderson 2010; Scanlon 2018).

22 In some sense, Rawls' list of primary social goods covers at least some such inherently relational goods by including the 'social bases of self-respect' (Rawls 1971, secs 15; 67).

23 Some might also adopt a stronger presumption of equality: if institutions generate deviations from perfect equality, such inequalities require a justification (Gosepath 2015). Some relational egalitarians might reject this presumption, maybe because they adopt sufficientarianism. I think such sufficientarian views fail to appreciate how inequality matters even at high levels of income and development (see footnote 9 and (Schemmel 2011; 2012)). In any case, such views can still accept the weaker requirement above that strong economic inequalities require justification.
} 
cannot participate on an equal footing in a cooperative system if procedures do not treat them equally.

Second, beyond merely procedural conditions, every participant also requires sufficient access to substantive opportunities to participate. For example, a lucrative job might be given to the candidate with the best relevant education independent of factors like class, race, and gender. Yet if some people, say members of the working class, could never afford any education, such jobs are not open to all. More generally, every participant should have sufficient access to opportunities that would enable her to participate in cooperative economic undertakings, otherwise she is not an equal participant. ${ }^{24}$

While vague, the two requirements provide enough of a background picture for me to now move on to my more specific arguments for (some) responsibilitysensitive distributions.

\subsection{The costless reneging argument}

The equal participation ideal includes the idea of cooperation for overall advantage. Cooperation for overall advantage requires division of labour and specialisation. For example, I could try to build a house all by myself in the woods, chopping down the trees myself, sawing the logs, and so on. But in an advanced economy, I can draw on division of labour and specialisation and thereby have a better house built more effectively. However, specialisation also creates dependencies. Whereas before my house just depended on my doing my job, now I depend on the contractors and producers doing theirs. In this sense, cooperation for overall advantage parcels out responsibilities and creates dependencies. Equal participants in a cooperative undertaking for overall advantage will join more specific cooperative undertakings. In so doing, participants typically agree to take on obligations towards others.

Acquired obligations and dependencies in cooperative undertakings matter for relational egalitarianism. When someone engages in what I call costless reneging, she acquires obligations to other participants, makes no serious effort to discharge them, yet bears no consequential responsibility. For example, imagine my neighbour promises to saw the logs for me if I do her gardening for a week first. Yet after I have done the gardening, she reneges on her obligation and stops speaking to me. As participants in a voluntarily created cooperative undertaking, she clearly treats me as unequal, because she fails to consider my justified interests as part of our cooperation. Worse still, the power configuration of our relationship allows her to just get away with it.

Costless reneging threatens relational equality. Other things equal, relational egalitarians ought to prefer institutions that do not facilitate costless reneging. Return to Equalia to see how institutions should not be. Institutions in Equalia seek to minimize synchronic relational inequality. In Lecturer, Tim takes on a job as university lecturer and thereby makes the university, his colleagues and his students

\footnotetext{
${ }^{24}$ Examples of how to fill in this requirement would be: Rawls' second principle (Rawls 1971, secs 11-4), Scanlon's recent suggestions (Scanlon 2018, chap. 5), Anderson's capability principles (Anderson 1999; 2008; 2010), and Mason's substantive opportunity principle (Mason 2006).
} 
depend on Tim doing his job. Yet Tim shirks on nearly all his acquired obligations. Now, because Equalia just concentrates on synchronic inequality going forward, Equalia might not allow the university to fire Tim. According to the Costless Reneging Argument, Equalia fails on the relational egalitarian ideal, because rather than preventing costless reneging, Equalia facilitates it. Here is the argument.

A. Other things equal, relational egalitarians recommend systems that prevent, or at least do not enable, diachronic relational inequality.

B. Costless reneging is a form of, or at least contributes to, diachronic relational inequality. [Someone engages in costless reneging, when she acquires obligations to other participants, does not discharge such obligations, bears no significant costs as a result, and it would be appropriate to hold her responsible (in the attributability sense) for acquiring the obligations and for not discharging them.]

C. Therefore, other things equal, relational egalitarians recommend systems that prevent, or at least do not enable, costless reneging. ${ }^{25}$

D. Systems that prevent, or at least do not enable costless reneging, make some economic distributions sensitive to personal responsibility and choice.

E. Therefore, other things equal, relational egalitarians recommend systems that make some economic distributions sensitive to personal responsibility and choice.

Premise $\mathrm{A}$ is just an implication of relational egalitarianism. I have motivated premise B above, including with the Lecturer example (I say a bit more about B below). A and B imply C. I now need to motivate premise D. To this end, consider how Equalia's responsibility-insensitive institutions would fail to secure relational equality.

First, by not assigning consequential responsibility, the university facilitates costless reneging. Equalia's institutions enable Tim to treat others as unequal. Tim's reneging on his obligations would not be costless, if they were met with appropriate consequences. For example, if other participants had the power to respond effectively, Tim would be forced to consider other people's interests. Accordingly, Tim could not so easily treat them as lesser participants in the cooperative undertaking. So, more generally, when we separate distributions from responsibility entirely, we might set up social structures that enable costless reneging and thereby diachronic relational inequality.

Second, Equalia's institutions might also express unequal regard. If the university in Equalia took no action in response to Tim's reneging, it might fail to treat other stakeholders as equal participants. For example, Jane - Tim's dutiful colleague could rightly complain that the university's policy of always securing synchronic equality fails to treat her and Tim as diachronically equal. For the university gives strongly different weights to their respective interests. Primarily, this worry is not

\footnotetext{
25 Sometimes things are not equal and making distributions responsibility-sensitive comes with costs or would itself generate relational inequality elsewhere. See my discussion in Sect. 6.1.
} 
about the subjective attitudes Tim and Jane have towards one another. Remember how in Carlton, relational inequality can be generated between two groups (or between individuals) when a third party treats them in a way that expresses unequal status. Arguably, the university and the state contribute to relational inequality in Lecturer by simply ignoring how Tim's reneging on his obligations affects others.

So, the Costless Reneging Argument holds that a society of equals would hold individuals responsible for the obligations they acquire towards others. Of course, sometimes informal reactive attitudes suffice. ${ }^{26}$ Other times, however, consequential responsibility will require economic consequences. And such economic consequences can lead to synchronic relational inequality.

Note that in premise B I stipulated that someone's behaviour only counts as costless reneging, and thus is a form of relational inequality, if it is appropriate to hold them responsible. And for that certain background conditions must apply. A person must have been in a position to genuinely acquire obligations in a way that makes it appropriate to hold her responsible for not discharging those obligations. To acquire obligations, consider three necessary conditions, two of which go back to the equal participation ideal.

First, the fundamental background institutions must be, at least, minimally justified, such that one can reasonably be expected to play by the rules provided others do so too. Imagine a poor day labourer in early twentieth century Bolivia working for a rich European landowner. If she gets away with doing a shoddy job, we would not think that this facilitates inegalitarian relations. The oppressive set-up makes relations in which the landowner is 'below' the labourer hard to imagine.

Second, to voluntarily acquire an obligation requires sufficient (and sufficiently good) options to do otherwise. A slave who runs away does not express antiegalitarian attitudes. But even in less drastic cases - for example when someone can only choose from a few highly oppressive jobs - does consequential responsibility seem diminished or, possibly, annulled.

Next, holding someone responsible for reneging is only appropriate if certain excusing conditions are absent. For example, my department head - reassuringly tells me that in Lecturer she would talk to Tim first and find out why he failed to fulfil his duties. If excusable personal issues apply, physical or mental illness for example, then rushing to negative consequential responsibility can be inappropriate. Instead, one might try other approaches first, such as temporary leave or part-time work. I say more on excusing conditions below. ${ }^{27}$

\footnotetext{
${ }^{26}$ As I discuss below, my arguments here do not imply that economic responsibility-sensitivity should always be the only or first response (Sect. 6.1). Sometimes informal reactive attitudes will suffice (also see footnote 17). But sometimes they won't, or so I assume: first, that we need intricate legal systems in civil law, such as contract law, is evidence that we also need formal responsibility-sensitivity; second, having some substantive control, for example legal recourse, over someone's power to renege (or otherwise impose costs) itself also helps reduce power inequalities.

27 'Excusing' conditions also imply 'justifying' conditions: we can imagine situations where one person's costless reneging was morally required all things considered, because of unforeseen countervailing moral reasons.
} 


\subsection{The cost imposition argument}

While it helps with Lecturer, the Costless Reneging Argument has its limits. For example, many of our relations - such as being patients in universal healthcare systems - are not 'acquired'. My second argument, the Cost Imposition Argument, has a wider purchase and helps with Lecturer and with Money Burner and Helicopter.

Relational egalitarian societies will require some institutions with solidaristic finances, such as universal healthcare and disability benefits. ${ }^{28}$ Again, we are back in Equalia where institutions focus only on synchronic equality. The Cost Imposition Argument now holds that Equalia's institutions would facilitate unequal treatment diachronically, because they facilitate that participants can impose costs on others in problematic ways.

Consider first the direct interpersonal relation in Money Burner and Helicopter. Petra the money burner acts in ways that she (should) know will create foreseeable, avoidable, and serious costs for others. She can foresee that she will be placed back into synchronic relational equality, with all the economic costs that entails for others. In ignoring these costs, she fails to treat others as equal participants. Or imagine that in Helicopter, the decision-makers toss a coin and end up buying a helicopter instead of the critical care device. Here, the reckless mountaineers fail to treat others as equals by acting in ways they know, or should know, might generate socialised costs and will take medical resources away from others.

Failing to treat others as equals can come with different attitudes. The money burner in Equalia intentionally imposed great costs onto others. The mountaineers, let us assume, knowingly accepted the foreseeable costs. They might not have intended to generate costs but accepted them as a side effect. Or we might assume that the mountaineers simply did not think about the costs and just acted negligently. Unequal regard and treatment thus do not require particularly nasty attitudes. Sometimes, lacking the right attitudes and behavioural dispositions can express unequal attitudes and treatment too. (We can make similar distinctions for costless reneging above.)

Attending to attitudes held by participants brings out one way in which cost imposition can thwart egalitarian relations. But, again, subjective attitudes and behaviour are typically not the full story. Relational inequality is often not simply reducible to the attitudes two persons have towards one another. In the above cases, Equalia's institutions are importantly involved in creating relational inequality in at least two ways. First, by not applying consequential responsibility, the state enables that some participants (such as Petra) can treat others as unequal. ${ }^{29}$ Second, Equalia's institutions themselves express unequal regard. Equalia does not distinguish between participants who avoid unnecessary costs and those who

\footnotetext{
${ }^{28}$ I make the reasonable, but undefended, assumption that they will require some such institutions without specifying precisely which and at what 'level' of solidarity.

${ }^{29}$ Of course, individuals can also view and treat others as unequal without such institutions. My claim here is that institutions such as Equalia's can enable and/or strengthen this kind of relational inequality, by, for example, imposing real costs on others.
} 
impose such costs, such as Petra the money burner or the mountaineers in Helicopter.

So, relational egalitarianism should avoid cost impositions. Doing so, they should make some distributions sensitive to responsibility. Here is a summary of the Cost Imposition Argument:

A. Other things equal, relational egalitarians recommend systems that prevent, or at least do not enable, diachronic relational inequality.

B. Cost imposition is a form of, or at least contributes to, diachronic relational inequality.

C. Therefore, other things equal, relational egalitarians recommend systems that prevent, or at least do not enable, cost imposition.

D. Systems that prevent cost imposition, or at least do not enable it, make some economic distributions sensitive to personal responsibility and choice.

E. Therefore, other things equal, relational egalitarians recommend systems that make some economic distributions sensitive to personal responsibility and choice.

Premise $\mathrm{A}$ is an implication of relational egalitarianism. I have motivated premise B above. A and B together imply C. I also motivated premise D above: imagining institutions that are entirely responsibility-insensitive shows why responsibility-sensitivity is (sometimes) needed to prevent cost impositions.

I still need to add some detail on premise B: in B I stipulated that some costgenerating behaviour - which I label 'cost imposition' - constitutes, or at least contributes to, diachronic relational inequality. However, not all cost-generating behaviour threatens relational inequality. So, what is the difference? Admittedly, there is no a priori and clear-cut criterion. But clear cases of cost imposition reveal some salient properties, the following three for example.

First, an agent had an alternative option to the cost-imposing behaviour that was not unreasonably costly to herself (where costliness is assessed relative to the costs incurred by society). For example, Petra had the option not to burn her money and not burning the money was not unreasonably costly for her. 'Costliness' is not limited to purely financial costs but should be read more broadly as 'opportunity costs' that include reductions in wellbeing, harm, frustration of important selfregarding or other-regarding goals, countervailing moral reasons and so on. ${ }^{30}$

Second, cost-imposing behaviour cannot apply to core opportunities that people are owed as equal participants in a relationally egalitarian society. For example, if someone decides to finish high school, they generate costs. Yet they generate such

\footnotetext{
30 Analogously, some luck egalitarians argue that individuals should carry consequential responsibility for option-luck only if they had reasonable alternatives ((Segall 2010; 2013) for example). Hyams objects that luck egalitarianism lacks a deeper rationale for the reasonableness condition (Hyams 2019). My arguments, in contrast, provide a relational egalitarian rationale for why reasonableness (and/or costliness) matters for cost imposition. When I can only avoid generating costs for others by incurring unreasonable costs to myself, then my cost-generating acts typically do not constitute treating others as unequal.
} 
costs by using opportunities owed to them by the equal participation ideal (opportunities also that many other people make use of).

Third, besides external choice conditions, further conditions must be met for cost-generating behaviour to involve unequal treatment or regard. First, such behaviour must meet epistemic conditions. Importantly, the costs a person generates must have been reasonably foreseeable. Second, the person must meet certain agency conditions. For example, imagine someone with a psychiatric condition going through a severe episode who needs to be sectioned and treated to prevent risk to themselves and others. While their behaviour generates costs, we should not hold them fully responsible. And, because we cannot hold them responsible, their costgenerating behaviour typically does not constitute unequal regard and/or treatment.

The Cost Imposition Argument can explain why egalitarians should favour responsibility-sensitive distributions in cases like Money Burner and Helicopter (and Lecturer).

But what about converse cases? We might think the Responsibility Challenge is also about explaining why lack of responsibility can be important. Luck egalitarians, for example, judge economic inequalities unjust, precisely when someone is not responsible for being worse off. Can relational egalitarianism account for such judgements too? For example:

Disability: Because Pedro was born with a physical disability, he has significantly fewer opportunities to earn an income than a comparable person without a disability.

Luck egalitarians would foreground that Pedro is not responsible for his disability. Accordingly, any resulting disadvantage is unjust, and Pedro is owed compensation. Relational egalitarians, in contrast, first shift the focus towards participation. Pedro's disability should not prevent him from standing on par with others and society ought to do what is necessary to integrate Pedro in productive and social life. For example, among other things, society ought to make physical adjustments in workspaces, support him with healthcare where necessary, and prevent ableist discrimination such that he can be an equal participant. Most issues are about synchronic equality. But the diachronic relational egalitarian perspective brings out why it also matters that Pedro cannot be held responsible for his disability. The greater-than-average costs required to fully integrate Pedro are not attributable to any cost-generating behaviour on Pedro's part that could express an inegalitarian attitude. Pedro did not choose to be disabled and his disability is not the result of him failing to consider other people's interests. So, additional costs resulting from Pedro's disability are not attributable to behaviour or attitudes that are inegalitarian towards others. Moreover, if the state spends more on Pedro than on participants without disabilities, the state does not enable cost impositions through which participants can treat each other as unequal. Nor does the state thereby itself express unequal regard and treatment between participants. Accordingly, relational egalitarianism brings out how Pedro's case differs from Lecturer, Money Burner, and Helicopter.

So, overall, relational egalitarianism shows why we should be concerned with personal responsibility and why such a concern sometimes justifies unequal 
economic distributions. What is more, responsibility sometimes justifies synchronic relational inequality. At the same time, relational egalitarianism shows why we often ought to do and spend more to help place individuals, for example individuals with disabilities, on par with others and why responsibility matters here too.

\section{Is this still relational egalitarianism?}

I have shown why and how relational egalitarianism should include personal responsibility. However, is this responsibility-sensitive version still in line with the original relational egalitarian project? I discuss two worries in particular. First, is responsibility-sensitive relational egalitarianism still properly egalitarian? Second, relational egalitarians have criticised luck egalitarians for placing so much weight on responsibility. Is responsibility-sensitive relational egalitarianism still compatible with this critique?

Start with the first worry.

\subsection{Is this still egalitarian?}

Foucauldians sometimes argue that discourse around personal responsibility ('responsibilisation') can act as an ideological cover to shift responsibility towards individuals and thereby hollow out collective responsibilities (Peeters, 2019). Does this worry apply here? Can relational egalitarianism integrate responsibility without threat to its egalitarian project?

Unfortunately, it is hard to say how much inequality my arguments justify. My abstract equal participation ideal and arguments above do not specify how frequent and large responsibility-sensitive inequalities should be. This will depend on various normative and empirically contingent considerations, particularly on the kinds of inequalities a society allows more generally through Institutional Justification. Moreover, I here talk about relational egalitarianism as a family of views. Different specific conceptions will differ in which responsibility-sensitive inequalities they will endorse. But despite such vagueness, relational egalitarianism includes several constraints that will prevent excessive inequalities.

First, relational egalitarianism is about both diachronic and synchronic relational equality. Even without a precise trade-off principle, relational egalitarians should object to institutions with widespread, persistent, and stark synchronic inequalities. A concern with synchronic relational equality thus severely constrains the size of responsibility-sensitive inequalities.

Second, a commitment to responsibility does not imply a commitment to always making distributions sensitive to responsibility nor to doing so in draconian ways. Informal negative reactive attitudes can sometimes be enough to protect diachronic equality. And sometimes mild distributive consequences might do just fine.

Third, some attempts at making distributions responsibility-sensitive can be unnecessary or counterproductive. For example, in some cooperative undertakings, enough people self-regulate their behaviour in egalitarian ways. A system of formal distributive implications might then not be necessary. Or establishing such a system 
might be costly or have other undesirable consequences, such as excessive surveillance or the weakening of self-regulatory behaviour.

Fourth, epistemic limitations constrain responsibility-sensitivity. For responsibility-sensitive distributions to be appropriate, we need to be epistemically confident that holding someone responsible is appropriate. For this, we must often collect evidence first. However, sometimes collecting evidence can itself engender relational inequality. Relational equality itself constrains how far the state should intrude into people's private lives to collect information and pass judgment (Anderson, 1999; Wolff, 1998). For example, welfare states must often choose between means-tested and unconditional benefits. Unconditional benefits are often not only more effective but also preferable from a relational egalitarian standpoint. They require less intrusion into people's private sphere and are more likely to reach those that need them (Atkinson, 2015, chap. 8; Wolff, 1998). Egalitarian reasons for unconditional benefits should then typically outweigh worries that benefits will not be responsibility-sensitive enough.

Finally, consider Helicopter. While persuasive, the example is very limited. Making health expenses conditional on lifestyle can intensify relational inequality and health disparities. For example, most health conditions with a behavioural aetiology - such as smoking-related conditions and obesity - have a socioeconomic gradient. $^{31}$ Moreover, epistemic points apply too: establishing responsibility might require intrusive fact-finding. Plus, the aetiology of behaviour-related conditions is riddled with empirical uncertainty. Was your health condition caused by your choices, genetic predisposition, socioeconomic circumstances, or all three together? To answer such questions is difficult and often close to impossible. For example, much recent literature is uncovering how the social environment of mothers during pregnancy can have drastic and surprising effects on the lives and behaviour of their children (Currie, 2011). Our epistemic limitations - alongside the limitations imposed by relational egalitarianism itself - thus speak against hasty impulses to make healthcare services and expenditures responsibility-sensitive.

While it vindicates some responsibility-sensitive inequalities, relational egalitarianism itself limits their size and scope. Relational egalitarians can integrate responsibility without threat to their egalitarian project.

\subsection{The relational critique of luck egalitarianism}

Relational egalitarians have criticised luck egalitarians for how they seek to integrate responsibility. The second worry is that my responsibility-sensitive version of relational egalitarianism is incompatible with this earlier critique.

Of course, my arguments move relational closer to luck egalitarianism: both seek to make some distributions sensitive to responsibility. At the same time, important differences remain. First, the two views differ on how they incorporate responsibility. I argued that relational egalitarianism should approach responsibility from

\footnotetext{
31 See (Wikler 2002; 2006) for further egalitarian arguments against responsibility-sensitive healthcare allocation.
} 
within relationships. Relational egalitarianism does not seek to integrate some external value of responsibility into social life. Instead, it focuses on how responsibility practices affect the quality of our relations. Most versions of luck egalitarianism, in contrast, take practice-independent metaphysical facts about responsibility as their input. ${ }^{32}$ Second, and relatedly, relational egalitarianism will provide different reasons for why we should incorporate responsibility: it is a concern with egalitarian relationships itself that generates reasons for holding people responsible. $^{33}$

Relational thus differs from luck egalitarianism in how and why it integrates responsibility. Such differences also keep relational egalitarians consistent with the objections they raise to luck egalitarianism. Here are two examples.

First, relational egalitarians have criticised that luck egalitarianism makes distributions choice-sensitive whether choices are altruistic or selfish (Anderson, 1999; Hausman, 2012). One person's choice to care for an elderly relative, for example, should not be treated the same as another person's selfish choices, even though both are responsible for their choices.

Responsibility-sensitive relational egalitarianism provides resources to explain why altruistic and selfish responsible behaviour should factor in differently. As argued above, relational egalitarianism considers how one's behaviour affects others and what social meaning such behaviour has. Imagine, for example, that the government financially compensates someone who cares for an elderly relative. In doing so, the state does not facilitate unequal relations: while the carer in some sense creates financial costs for society, their care work does not express an inegalitarian attitude or treatment of others. They create those costs to support a person in need and thus, in a sense, give back to society. Conversely, relational egalitarianism explains why the case is different when someone creates costs for society for purely selfish reasons. For example, imagine Tim slacks off in Lecturer so he can play video games all day. Tim creates costs for others without giving back anything of value. So, while both the carer and Tim might be responsible for their 'cost-generating' behaviour, relational egalitarianism gives us egalitarian reasons to treat them differently.

Second, some relational egalitarians argue that luck egalitarians lack a deeper justification for their focus on distributive equality and responsibility and for how they specify responsibility conditions the way they do (Hausman, 2012, 41-42; Hyams, 2013).

I have argued that relational egalitarianism makes the case for responsibility from within egalitarianism. Accordingly, it provides a coherent explanation as to why and how, as egalitarians, we should care about responsibility.

So, relational egalitarians can consistently invoke responsibility-sensitivity whilst also raising objections to how luck egalitarians treat responsibility. Of course, I here

\footnotetext{
32 At least, this applies to most (but not all) luck egalitarian views. Dworkin, for example, is an exception. Also see (McTernan 2016) for more on this contrast.

33 Dworkin and Stemplowska here might be exceptions within luck egalitarianism.
} 
neither defend such objections nor assume they are sound. ${ }^{34}$ I merely argued that they do not generate $t u$ quoque problems for relational egalitarianism.

\section{Conclusions}

In this article, I have provided a relational egalitarian framework for responsibility. My first set of arguments showed that a commitment to valuable egalitarian relationships commits us to dispositions to hold one another responsible. Implicit in relational equality itself is a commitment to personal responsibility. In a next step, I showed how relational egalitarianism should focus on both synchronic and diachronic relational equality. The latter, I argued, sometimes requires economic distributions to be sensitive to responsibility. Thereby, relational egalitarianism can justify (some) distributive and even some synchronic relational inequalities. Overall, relational egalitarianism offers a nuanced and unified account of why and how responsibility matters from within egalitarianism. That it does is an important argument in its favour.

Acknowledgements I would like to thank two anonymous reviewers at Philosophical Studies as well as Kai Spiekermann, Andreas Bengtson, and Ryan Doody for helpful written comments. I would also like to thank audiences at the Grundlegung session in Groningen and at the European Congress for Analytical Philosophy in Utrecht for helpful comments.

Open Access This article is licensed under a Creative Commons Attribution 4.0 International License, which permits use, sharing, adaptation, distribution and reproduction in any medium or format, as long as you give appropriate credit to the original author(s) and the source, provide a link to the Creative Commons licence, and indicate if changes were made. The images or other third party material in this article are included in the article's Creative Commons licence, unless indicated otherwise in a credit line to the material. If material is not included in the article's Creative Commons licence and your intended use is not permitted by statutory regulation or exceeds the permitted use, you will need to obtain permission directly from the copyright holder. To view a copy of this licence, visit http:// creativecommons.org/licenses/by/4.0/.

\section{References}

Anderson, E. (1999). What is the point of equality? Ethics, 109(2), 287-337. https://doi.org/10.1086/ 233897

Anderson, E. (2008). Expanding the egalitarian toolbox: equality and bureaucracy. Aristotelian Society Supplementary, 82(1), 139-160. https://doi.org/10.1111/j.1467-8349.2008.00166.x

Anderson, E. (2010). The fundamental disagreement between luck egalitarians and relational egalitarians. Canadian Journal of Philosophy, 40(S1), 1-23.

Arneson, R. J. (1989). Equality and equal opportunity for welfare. Philosophical Studies: An International Journal for Philosophy in the Analytic Tradition, 56(1), 77-93.

Arneson, R. J. (1991). A defense of equal opportunity for welfare. Philosophical Studies: An International Journal for Philosophy in the Analytic Tradition, 62(2), 187-195.

Atkinson, A. B. (2015). Inequality. Harvard University Press.

Barrett, J. (2020). Optimism about responsibility. Philosophers' Imprint, 20(33), 1-17.

\footnotetext{
34 Of course, luck egalitarians also respond to such objections, see footnote 5 .
} 
Cohen, G. A. (1989). On the currency of egalitarian justice. Ethics, 99(4), 906-944. https://doi.org/10. $1086 / 293126$

Cohen. (2009a). Rescuing justice and equality. Harvard University Press.

Cohen. . (2009b). Why not socialism? Princeton University Press.

Cohen. (2013). Finding oneself in the other. Otsuka, M. (Ed.) Princeton University Press.

Cordelli, C. (2015). Justice as fairness and relational resources. Journal of Political Philosophy, 23(1), 86-110. https://doi.org/10.1111/jopp.12036

Currie, J. (2011). Inequality at birth: some causes and consequences. The American Economic Review, 101(3), 1-22.

Duff, R. A. (2003). Punishment, communication, and community. Oxford University Press.

Dworkin, R. (1981). What is equality? part 2: equality of resources. Philosophy \& Public Affairs, 10(4), 283-345.

International Panel on Social Progress (ed.) (2018). Rethinking society for the 21st century: volume 1, socio-economic transformations: report of the international panel on social progress. Cambridge University Press.

Elford, G. (2017). Survey article: relational equality and distribution. Journal of Political Philosophy, 25(4), e80-99. https://doi.org/10.1111/jopp.12139

Eyal, N. (2006). Egalitarian justice and innocent choice. Journal of Ethics and Social Philosophy, 2(1), $1-19$.

Eyal, N. (2016). Luck Egalitarianism, Harshness, and the Rule of Rescue. In S. Matthew Liao \& C. O’Neil (Eds.), Current controversies in bioethics (pp. 160-171). Routledge.

Fleurbaey, M. (1995). Equal opportunity or equal social outcome? Economics and Philosophy, 11(1), 25.

Fleurbaey, M. (2008). Fairness, responsibility, and welfare. Oxford University Press.

Fourie, C., Schuppert, F., \& Wallimann-Helmer, I. (2015). Social equality: on what it means to be equals. Oxford University Press.

Fraser, N., \& Honneth, A. (2003). Redistribution Or recognition?: a political-philosophical exchange. Verso.

Fricker, M. (2007). Epistemic injustice: power and the ethics of knowing. Clarendon Press.

Fricker, M. (2016). What's the point of blame? a paradigm based explanation. Noûs, 50(1), 165-183.

Fricker, M. (2019). Risk, responsibility, and choice: why should some choices justify disadvantage while others don't? Social Theory and Practice, 45(1), 21-41. https://doi.org/10.5840/ soctheorpract 20191350

Garrau, M., \& Laborde, C. (2015). Relational equality, non-domination, and vulnerability. In C. Fourie, F. Schuppert, \& I. Wallimann-Helmer (Eds.), Social equality: On what it means to be equals (pp. 46-64). Oxford University Press. https://doi.org/10.1093/acprof:oso/9780199331109.001.0001.

Gheaus, A. (2016). Hikers in flipflops: Luck egalitarianism, democratic equality and the distribuenda of justice. Journal of Applied Philosophy, 33(1), 54-69.

Gosepath, S. (2015). The principles and the presumption of equality. In C. Fourie, F. Schuppert, \& I. Wallimann-Helmer (Eds.), Social equality: on what it means to be equals (pp. 107-126). Oxford University Press.

Gruen, C., \& Stephan, K. (2013). Income, inequality, and subjective well-being: an international and intertemporal perspective using panel data. Jahrbuch Für Wirtschaftsgeschichte/Economic History Yearbook, 54(1), 15-35.

Hausman, D. M. (2012). What's wrong with global health inequalities. In P. Tamara Lenard \& C. Straehle (Eds.), Health inequalities and global justice. Edinburgh University Press.

Holroyd, J. (2007). A communicative conception of moral appraisal. Ethical Theory and Moral Practice, 10(3), 267-278. https://doi.org/10.1007/s10677-007-9067-5

Honneth, A. (1992). Kampf um Anerkennung. Suhrkamp.

Hume, D. (1739). A treatise of human nature. In L. A. Selby-Bigge (Ed.). 1978th ed. Clarendon Press.

Hyams, K. (2013). Equality, responsibility, and the balance of interests. Journal of Social Philosophy, 44(4), 392-401.

Knight, C. (2006). The metaphysical case for luck egalitarianism. Social Theory and Practice, 32(2), $173-189$.

Knight, C. (2009). Luck egalitarianism: equality, responsibility, and justice. Edinburgh University Press.

Koch, I. (2019). Personalizing the state: an anthropology of law, politics, and welfare in austerity Britain. Oxford University Press.

Kolodny, N. (2014). Rule over none II: social equality and the justification of democracy. Philosophy \& Public Affairs, 42(4), 287-336. https://doi.org/10.1111/papa.12037 
Kolodny, N. (2019). Being under the power of others. In Y. Elazar \& R. Genevieve (Eds.), Republicanism and the future of democracy (pp. 94-114). Cambridge University Press.

Krause, S. R. (2013). Beyond non-domination: agency, inequality and the meaning of freedom. Philosophy and Social Criticism, 39(2), 187-208.

Kymlicka, W. (2002). Contemporary political philosophy: an introduction. Oxford University Press.

Laborde, C., \& Maynor, J. (2009). Republicanism and political theory. Blackwell Publishing.

Lippert-Rasmussen, K. (2015). Luck egalitarianism. Bloomsbury Publishing.

Lippert-Rasmussen, K. (2018). Relational egalitarianism: living as equals. Cambridge University Press.

Lovett, F. (2010). A general theory of domination and justice. Oxford University Press.

Mason, A. (2006). Levelling the playing field: the idea of equal opportunity and its place in egalitarian thought. Oxford University Press.

McGeer, V. (2012). Civilizing blame. In D. Justin Coates \& N. A. Tognazzini (Eds.), Blame: Its nature and norms (pp. 162-188). Oxford University Press.

McGeer, V. (2014). P.F. Strawson's consequentialism. In D. Shoemaker \& N. A. Tognazzini (Eds.), Oxford studies in agency and responsibility (Vol. 2, pp. 64-92). Oxford University Press.

McKenna, M. (2012). Conversation \& responsibility. Oxford University Press.

McKerlie, D. (1989). Equality and time. Ethics, 99(3), 475-491.

McKerlie, D. (2001). Justice between the young and the old. Philosophy and Public Affairs, 30(2), $152-177$.

McTernan, E. (2016). How to be a responsibility-sensitive egalitarian: from metaphysics to social practice. Political Studies, 64(3), 748-764. https://doi.org/10.1111/1467-9248.12208

Miller, D. (1997). Equality and justice. Ratio, 10(3), 222-237.

Miller, D. (1999). Principles of social justice. Harvard University Press.

Moles, A., \& Parr, T. (2019). Distributions and relations: a hybrid account. Political Studies, 67(1), 132-148. https://doi.org/10.1177/0032321718755589

Morgan, C., Burns, T., Fitzpatrick, R., Pinfold, V., \& Priebe, S. (2007). Social exclusion and mental health: conceptual and methodological review. The British Journal of Psychiatry, 191(6), 477-483. https://doi.org/10.1192/bjp.bp.106.034942

O’Neill, M. (2008). What should egalitarians believe? Philosophy \& Public Affairs, 36(2), 119-156.

O'Neill, M. (2010). The facts of inequality. Journal of Moral Philosophy, 7(3), 397-409. https://doi.org/ $10.1163 / 174552410 X 511383$

Oishi, S., Selin, K., \& Ed, D. (2011). Income inequality and happiness. Psychological Science, 22(9), 1095-1100. https://doi.org/10.1177/0956797611417262

Peeters, R. (2014). Just freedom: a moral compass for a complex world. W. W. Norton \& Company.

Peeters, R. (2019). Manufacturing responsibility: the governmentality of behavioural power in social policies. Social Policy and Society, 18(1), 51-65. https://doi.org/10.1017/S147474641700046X

Pettit, P. (2001). A theory of freedom: from the psychology to the politics of agency. Polity.

Pickett, K. E., \& Wilkinson, R. G. (2015). Income inequality and health: a causal review. Social Science \& Medicine, 128(March), 316-326. https://doi.org/10.1016/j.socscimed.2014.12.031

Pogge, T. W. (1995). Three problems with contractarian-consequentialist ways of assessing social institutions. Social Philosophy and Policy, 12(2), 241-266.

Rakowski, E. (1991). Equal justice. Clarendon Press.

Rawls, J. (1971). A theory of justice. Harvard University Press.

Roemer, J. E. (2000). Equality of opportunity. Harvard University Press.

Russell, P. (2002). Freedom and moral sentiment: hume's way of naturalizing responsibility. Oxford University Press.

Scanlon, T. M. (1998). What we owe to each other. Harvard University Press.

Scanlon, T. M. (2008). Moral dimensions. Harvard University Press.

Scanlon, T. M. (2018). Why does inequality matter? Oxford University Press.

Scheffler, S. (2003). What is egalitarianism? Philosophy \& Public Affairs, 31(1), 5-39.

Scheffler, S. (2015). The practice of equality. In C. Fourie, F. Schuppert, \& I. Wallimann-Helmer (Eds.), Social equality (pp. 20-44). Oxford University Press.

Schemmel, C. (2011). Why relational egalitarians should care about distributions. Social Theory and Practice, 37(3), 365-390.

Schemmel, C. (2012). Distributive and relational equality. Politics, Philosophy \& Economics, 11(2), 123-148. https://doi.org/10.1177/1470594X11416774

Schmidt, A. T. (2018). Domination without inequality? mutual domination, republicanism, and gun control. Philosophy \& Public Affairs, 46(2), 175-206. https://doi.org/10.1111/papa.12119 
Schuppert, F. (2012). Suffering from social inequality: normative implications of empirical research on the effects of inequality. Philosophical Topics, 40(1), 97-115.

Segall, S. (2010). Health, luck, and justice. Princeton University Press.

Segall, S. (2013). Equality and opportunity. Oxford University Press.

Skinner, Q. (2012). Liberty before liberalism. Cambridge University Press.

Spiegelberg, H. (1944). A defense of human equality. The Philosophical Review, 53(2), 101-124. https:// doi.org/10.2307/2182019

Stemplowska, Z. (2008). Holding people responsible for what they do not control. Politics, Philosophy and Economics, 7(4), 355-377.

Stemplowska, Z. (2009). Making justice sensitive to responsibility. Political Studies, 57(2), 237-259. https://doi.org/10.1111/j.1467-9248.2008.00731.x

Stemplowska, Z. (2011). Responsibility and respect: reconciling two egalitarian visions. In C. Knight \& Z. Stemplowska (Eds.), Responsibility and distributive justice (pp. 115-135). Oxford University Press.

Stemplowska, Z. (2013). Rescuing luck egalitarianism. Journal of Social Philosophy, 44(4), 402-419.

Strawson, P. F. (1962). Freedom and resentment. Proceedings of the British Academy, 48, 1-25.

Sunstein, C. R. (1988). Beyond the republican revival. The Yale Law Journal, 97(8), 1539-1590. https:// doi.org/10.2307/796540

Tan, K.-C. (2008). A defense of luck egalitarianism. Journal of Philosophy, 105(11), 665-690.

Tan, K.-C. (2012). Justice, institutions, and luck: the site, ground, and scope of equality. Oxford University Press.

Tawney, R. H. (1931). Equality. George Allen and Unwin.

Vargas, M. (2013). Building better beings: a theory of moral responsibility. Oxford University Press.

Viehoff, D. (2014). Democratic equality and political authority. Philosophy \& Public Affairs, 42(4), 337-375. https://doi.org/10.1111/papa.12036

von Hirsch, A. (1996). Censure and sanctions. Clarendon Press.

Wallace, R. J. (1994). Responsibility and the moral sentiments. Harvard University Press.

Wellman, C. H. (2008). Immigration and freedom of association. Ethics, 119(1), 109-141. https://doi.org/ $10.1086 / 592311$

Wikler, D. (2002). Personal and social responsibility for health. Ethics \& International Affairs, 16(2), 47-55. https://doi.org/10.1111/j.1747-7093.2002.tb00396.x

Wikler, D. (2006). Personal and social responsibility for health. In S. Anand, F. Peter, \& A. Sen (Eds.), Public health, ethics, and equity (pp. 109-134). Oxford University Press.

Wolff, J. (1998). Fairness, respect, and the egalitarian ethos. Philosophy \& Public Affairs, 27(2), 97-122.

Wolff, J. (2015). Social equality and social inequality. In C. Fourie, F. Schuppert, \& I. Wallimann-Helmer (Eds.), Social equality: on what it means to be equals (pp. 209-226). Oxford University Press.

Wolff, J., \& de-Shalit, A. (2013). Disadvantage. Oxford University Press.

Wood, D. (2010). Punishment: nonconsequentialism. Philosophy Compass, 5(6), 470-482. https://doi.org/ 10.1111/j.1747-9991.2010.00288.x

Young, I. M. (1990). Justice and the politics of difference. Princeton University Press.

Publisher's Note Springer Nature remains neutral with regard to jurisdictional claims in published maps and institutional affiliations. 